\title{
Effect of Planting Density and Nutrient Management Practices on the Growth Parameters of Maize Hybrids under Temperate Conditions of Kashmir
}

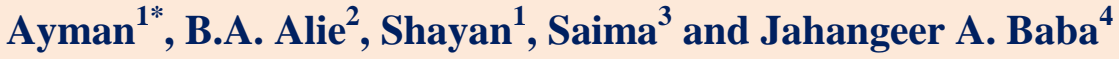 \\ ${ }^{1}$ Division of Agronomy, FOA/ RRS, Wadura, India \\ ${ }^{2}$ Agronomy, Saffron research station, Konnibal, Pampore, India \\ ${ }^{3}$ Division of Basic Sciences \& Humanities, FOA /RRS, Wadura, India \\ ${ }^{4}$ KVK/ETC, Malangpora, Pulwama, India \\ Sher-e-Kashmir University of Agricultural Sciences and Technology of Kashmir, India \\ *Corresponding author
}

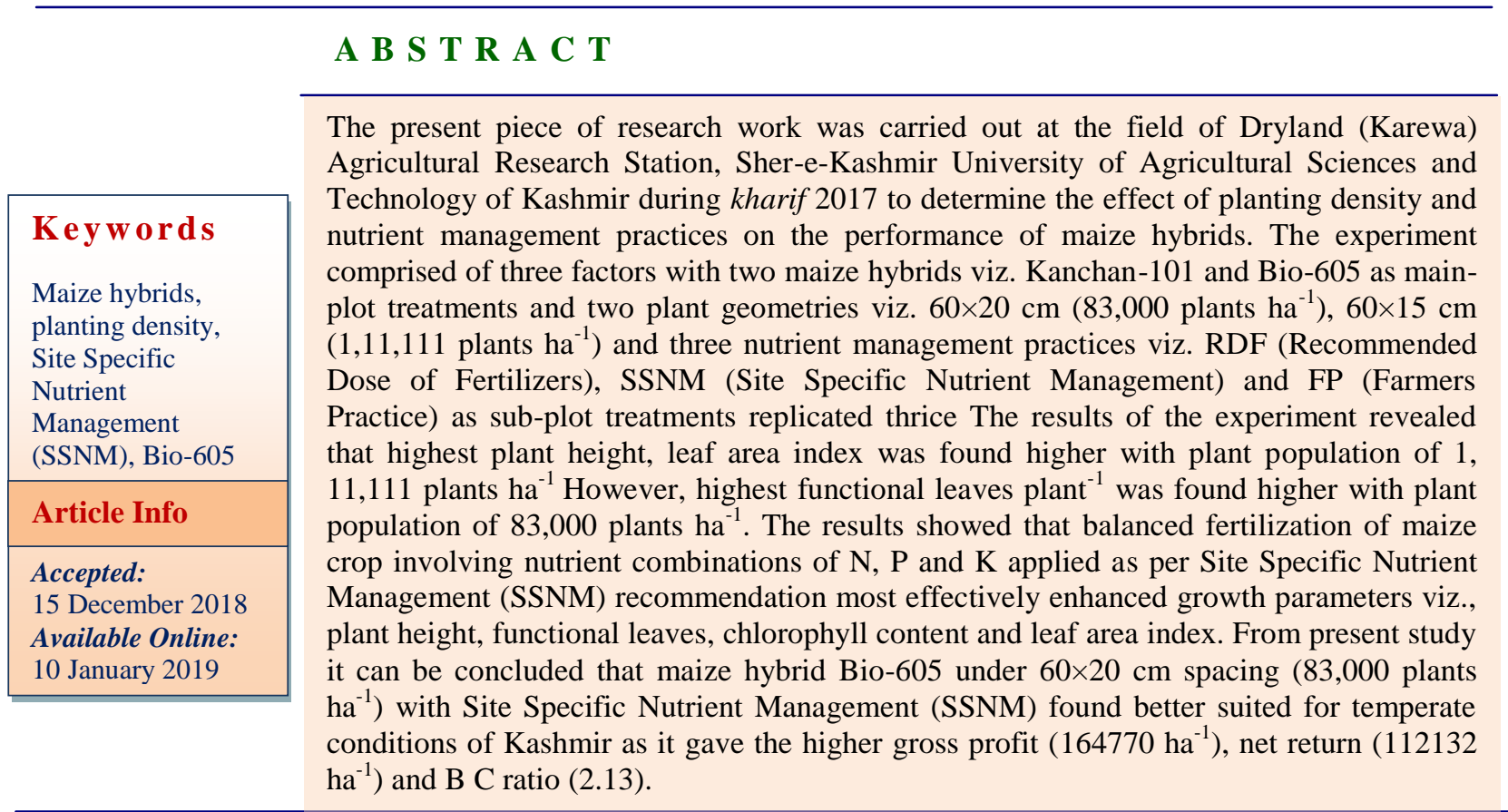

\section{Introduction}

Among cereals, maize (Zea mays L.) ranks first in total world production and it is staple food in many countries, particularly in the tropics and sub-tropics. Globally maize is cultivated over an area of 179 million ha with a production and productivity of 967 million tonnes and $5.7 \mathrm{t} \mathrm{ha}^{-1}$, respectively (Special maize report 2016). In India maize is 
contributing around 24 per cent of total cereal production (Singh et al., 2011). In India it is cultivated over an area of 9.9 million ha with 26.3 million tonnes production having an average productivity of $2.6 \mathrm{t} \mathrm{ha}^{-1}$ (Economic survey, 2017-18).

In the State of Jammu and Kashmir maize is cultivated over an area of around 3.1 lakh hectares with the production of 52.7 lakh quintals and productivity of $1.7 \mathrm{t} \mathrm{ha}^{-1}$ (Anonymous, 2015). It is the second important crop after rice in the state and is a staple food of tribal such as Gujar and Bakarwall (nomadic race). Maize is generally grown under rain fed conditions and on marginal lands particularly in hilly terrains of the Kashmir valley invariably as mixed crop with pulses (Pole type beans).

Optimum plant population is one of the important factors for higher productivity, by virtue of which there is efficient utilization of underground resources and also harvesting maximum solar radiation which in turn results in better photosynthesis (Monneveux et al., 2005). An optimum plant population for maximum economic yield exists for all crop species and varies with cultivar and environment (Bruns and Abbas, 2005). Modern maize hybrids tolerate higher plant densities than hybrids used in past and the use of narrow rows has greater potential to enhance grain yield at crowded stands (Sangoi et al., 2002). New generation of maize cultivars are characterized by a better ability of plant to be grown in denser stand as they were selected under such conditions (Peykarestan and Seify, 2012). Thus, there is a need to work out optimum plant population of hybrids by adjusting inter row spacing under prevailing agro-climatic conditions.

In order to achieve higher cob yield, maintenance of stand density is the most important factor. A spatial arrangement of plant governs the shape and size of the leaf area plant ${ }^{-1}$, which in turn influences efficient interception of radiant energy and proliferation and growth of shoots and their activity. Maximum yield can be expected only when plant population allows individual plants to achieve their maximum inherent potential (Aravinth et al., 2011). Maize is categorized as a very exhaustive crop because of its extremely high demand for the nutrients specially nitrogen, phosphorus and potassium from the soil. Nitrogen is an essential component of amino acids, which are the building blocks of proteins and is also a part of the DNA molecule, so it plays a very important role in cell division and reproduction. The chlorophyll molecule also contains nitrogen. Nitrogen deficiency most often results in slow and stunted growth along with chlorosis. Most of the nitrogen taken up by plants from the soil is in the forms of $\mathrm{NO}_{3}{ }^{-}$. Amino acids and proteins can only be built from $\mathrm{NH}_{4}^{+}$so $\mathrm{NO}_{3}$ has to be reduced with split application of ammonical form of nitrogen. Nitrogen is usually applied in splits in the field to avoid various nitrogen losses. Split application facilitates the crop N requirements at the time of need of the crop.

Blanket as well as predetermined recommended application of fertilizers by most of the farmers in the zone irrespective of soil, varieties, climate and farming situation not only wastes fertilizer resources but also fails to increase productivity substantially as the recommendations are either over estimated or under estimated due to diverse heterogeneous nature of soil. Such recommendations assume that the need of maize crop for nutrients is constant over time and over large areas. Hence there is an urgent need to identify the recent nutrient management approaches, which can increase nutrient use efficiency from view point of fertilizer costs and environmental concerns as well as productivity of crops on sustainable 
basis. Productivity of maize is also limited by low fertilizer efficiency, inadequacy in existing fertilizer recommendation and ignorance of nutrient balance and hence, serious constraint in maize production.

The novel approach of site specific nutrient management (SSNM) involves science based principles for guiding the judicious and efficient application of fertilizer as and when needed by crop. The nutrient expert for maize is a new computer- based decision support tool developed to assist local experts to quickly formulate fertilizer guidelines for maize fields on the principles of Site-Specific Nutrient management (SSNM). There exists a significant opportunity to increase fertilizer efficiency and productivity of maize by adopting nutrient expert-based field specific fertilizer recommendations (Satyanarayana et al., 2013).

\section{Materials and Methods}

A field experiment was conducted at Dryland (Karewa) Agricultural Research Station, Sher-e-Kashmir University of Agricultural Sciences and Technology of Kashmir during kharif 2017. The site is situated between $34.6^{\circ} \mathrm{N}$ and $74.5^{\circ} \mathrm{E}$ at an altitude of 1580 above mean sea level. The experiment was laid in split plot design with three replications which consisted of twelve treatments.

\section{Treatment details}

\section{Maize hybrids (main plot)}

Kanchan 101:( $\left.\mathrm{H}_{1}\right)$

Bio $605:\left(\mathrm{H}_{2}\right)$

\section{Plant density (sub-plot)}

$60 \mathrm{~cm} \times 20 \mathrm{~cm} \quad\left(83000\right.$ plants ha $\left.{ }^{-1}\right) \quad:\left(\mathrm{D}_{1}\right)$ $60 \mathrm{~cm} \times 15 \mathrm{~cm} \quad\left(111111\right.$ plants ha $\left.{ }^{-1}\right):\left(\mathrm{D}_{2}\right)$

\section{Nutrient management practices (sub-plot)}

Recommended Dose of Fertilizer: $\quad\left(\mathrm{N}_{1}\right)$ Site Specific Nutrient Management: $\left(\mathrm{N}_{2}\right)$ Farmer's Practice: $\left(\mathrm{N}_{3}\right)$

\section{Other experimental details}

Design: Split plot

Replications: 03

No. of Treatment combinations: 12

Season: Kharif, 2017

Total no. of Plots: 36

Plot size: $15 \mathrm{~m}^{2}$

\section{Fertilizer application}

Fertilizer application was made as per the treatment. Full dose of phosphorus and potassium, zinc and half dose of nitrogen were applied at the time of sowing by drilling fertilizer in crop rows about $4-5 \mathrm{~cm}$ below the seeds. The remaining nitrogen was given at knee high stage as top dressing. FYM was also applied.

\section{Seed and sowing}

Maize hybrids (Kanchan-101and Bio-605) were sown at the seed rate $20 \mathrm{~kg} \mathrm{ha}^{-1}$ on $20^{\text {th }}$ May, 2017.

Furrows were opened at $60 \mathrm{~cm} \times 20 \mathrm{~cm}$ and 60 $\mathrm{cm} \times 15 \mathrm{~cm}$ apart respectively as per the treatment combination and seeds were placed at a depth of 3-4 cm in the furrows already opened for fertilizer application.

\section{Irrigation}

Irrigation was given to the crop as and when required depending upon the moisture availability in the soil. Great care was taken to ensure the moisture availability in the soil throughout crop growth period. 


\section{Weed management}

In order to minimize weed competition, preemergence application of Atrazine $(1 \mathrm{~kg}$ a.i in 1000 litre of water) followed by one hoeing and earthing up at 25 DAS was carried out.

\section{Thinning}

In order to maintain plant to plant distance of $20 \mathrm{~cm}$ and $15 \mathrm{~cm}$ desired plant population as per treatment, thinning was done 15 days after sowing.

\section{Plant protection measures}

Chlorpyrifos was applied @ $20 \mathrm{~kg} \mathrm{ha}^{-1}$.

\section{Observations recorded}

For recording data, five plants were randomly selected from the penultimate rows, tagged from every plot of each replication and used for recording of various characteristics of crops at different stages of maize growth. The average for every parameter was calculated and recorded after prescribed intervals. Various growth parameters viz., plant height; numbers of functional leaves per plant, leaf area index of maize were evaluated at 30 days interval.

\section{Statistical analysis}

All the data were subjected to statistical analysis by adopting appropriate method of analysis of variance as described by Cochran and Cox (1967). Wherever the F value was found significant at 5 per cent level of probability, the critical difference $(\mathrm{CD})$ value were computed for comparing treatment means.

\section{Results and Discussion}

The data on plant height of maize plant as influenced by maize hybrids, planting densities and nutrient management practices were recorded at 30 day interval and statistically analyzed data observed during the course of investigation have been presented in Table 1. Plant height is an important growth parameter to study the accumulation of dry matter by the plant and is very important to examine the overall canopy architecture of the plant and also regulate the orientation of the leaves that further govern the photosynthetic efficiency of a plant to utilize the natural resources. The data showed that the plant population 1, 11,111 plants $\mathrm{ha}^{-1}$ recorded significant and consistent increase in plant height at all the stages of growth as compared to 83,000 plants ha ${ }^{-1}$. Also that plant height recorded under application of SSNM was significantly superior over RDF and FP. The increased plant populations intensified interplant competition for light and stimulate apical dominance and lengthening internodes. Accordingly Plant height is greater under high density (Mandić 2011). Under the present investigation, profound effect of balanced and optimum increased fertilization on various growth parameters of the crop appears to help in enrichment of soil with this nutrient status, resulted in better availability of nutrients for growth and development of plant height at early stage. Thus better nutritional environment in plants under the influence of managed fertilization based on site specific nutrient management seems to have promoted height of plants and growth of individual leaf by way of active cell division, elongation and even improved chlorophyll synthesis. The larger canopy development and plant height under the application of optimum dose of fertilizer might have increased interception, absorption and utilization of radiant energy, photosynthesis.

The data on leaf area index of maize plant as influenced by maize hybrids, planting densities and nutrient management practices were recorded at 30 day interval and statistically analyzed data observed during the 
course of investigation have been presented in Table 1. Leaf area index was not significantly influenced by plant population at knee high stage, however highest leaf area index was recorded under 1, 11,111 plants $\mathrm{ha}^{-1}$ at tasseling and maturity. Also, SSNM recorded highest LAI at knee high, tasseling and at maturity over RDF and FP and similarly RDF also recorded higher LAI at knee high, tasseling and at maturity over FP. Highest physiological growth indices are achieved under high plant density, because photosynthesis increases by development of leaf area. In our research, the increase in LAI explains the general crop trends that increasing plant density increases leaf area index on account of more area occupied by green canopy of plants per unit area. Previous research findings also indicated that in high maize density, leaf area index, total dry weight increased than low maize density throughout crop growth season (Abuzar et al.,2011, Bhatt et al., 2012, Thakur et al., 2015). $\mathrm{N}$ fertilizer can increase maize growth rate by promoting the leaf area index and the photosynthetic source and sink (Uhart and Andrade, 1995).

The data on functional leaves plant ${ }^{-1}$ of maize plant as influenced by maize hybrids, planting densities and nutrient management practices were recorded at 30 day interval and statistically analyzed data observed during the course of investigation have been presented in Table 1. No. of functional leaves plant ${ }^{-1}$ at 60 , 90 and 120 DAS were found significantly higher in plant population 83,000 plants $\mathrm{ha}^{-1}$ by $16.78,6.75$ and 13.0 per cent, respectively over 1,11,111 plants $\mathrm{ha}^{-1}$. However, at 30 DAS it was found non-significant. Also No. of functional leaves plant ${ }^{-1}$ at 60, 90 and 120 DAS were found significantly higher in SSNM over RDF and FP. However, at 30 DAS it was found non-significant.

Table.1 Effect of maize hybrids, plant geometry and nutrient management practices on number of functional leaves plant ${ }^{-1}$ at 30 days interval

\begin{tabular}{|c|c|c|c|c|}
\hline Treatments & 30 DAS & 60 DAS & 90 DAS & 120 DAS \\
\hline \multicolumn{5}{|l|}{ Hybrid } \\
\hline Kanchan-101 & 6.02 & 9.10 & 12.92 & 10.97 \\
\hline Bio-605 & 6.20 & 10.01 & 13.42 & 11.63 \\
\hline S.E $(\mathbf{m}) \pm$ & 0.10 & 0.16 & 0.22 & 0.12 \\
\hline $\mathrm{CD}(\mathrm{P} \leq 0.05)$ & NS & NS & NS & NS \\
\hline \multicolumn{5}{|l|}{ Plant density } \\
\hline $60 \times 20 \mathrm{~cm}\left(83000\right.$ plants $\left.\mathrm{ha}^{-1}\right)$ & 6.27 & 10.30 & 13.60 & 11.99 \\
\hline $60 \times 15 \mathrm{~cm}\left(111111\right.$ plants $\left.\mathrm{ha}^{-1}\right)$ & 6.11 & 8.82 & 12.74 & 10.61 \\
\hline S.E $(\mathrm{m}) \pm$ & 0.13 & 0.08 & 0.17 & 0.34 \\
\hline $\mathrm{CD}(\mathrm{P} \leq \mathbf{0 . 0 5})$ & NS & 0.33 & 0.68 & 1.35 \\
\hline \multicolumn{5}{|l|}{ Nutrient Management Practices } \\
\hline Recommended Dose of Fertilizer (RDF) & 6.15 & 9.88 & 13.27 & 11.18 \\
\hline $\begin{array}{l}\text { Site Specific Nutrient Management } \\
\text { (SSNM) }\end{array}$ & 6.38 & 11.05 & 14.48 & 13.30 \\
\hline Farmers Practice (FP) & 6.03 & 7.75 & 11.77 & 9.42 \\
\hline S.E $(\mathrm{m}) \pm$ & 0.23 & 0.22 & 0.24 & 0.29 \\
\hline $\mathrm{CD}(\mathrm{P} \leq \mathbf{0 . 0 5})$ & NS & 0.65 & 0.72 & 0.88 \\
\hline
\end{tabular}


Table.2 Effect of maize hybrids, plant geometry and nutrient management practices on chlorophyll index (Chlorophyll meter readings) at different phenological stages

\begin{tabular}{|c|c|c|c|}
\hline Treatments & Knee high & Tasseling & At Harvest \\
\hline \multicolumn{4}{|l|}{ Hybrid } \\
\hline Kanchan-101 & 31.21 & 44.47 & 25.59 \\
\hline Bio-605 & 32.36 & 46.49 & 26.63 \\
\hline S.E $(\mathbf{m}) \pm$ & 0.58 & 0.75 & 0.45 \\
\hline $\mathrm{CD}(\mathrm{P} \leq \mathbf{0 . 0 5})$ & NS & NS & NS \\
\hline \multicolumn{4}{|l|}{ Plant density } \\
\hline $60 \times 20 \mathrm{~cm}\left(83000\right.$ plants ha $\left.^{-1}\right)$ & 32.10 & 46.02 & 26.37 \\
\hline $60 \times 15 \mathrm{~cm}\left(111111\right.$ plants $\left.\mathrm{ha}^{-1}\right)$ & 31.47 & 44.95 & 25.85 \\
\hline S.E $(\mathbf{m}) \pm$ & 0.31 & 0.57 & 0.51 \\
\hline $\mathrm{CD}(\mathrm{P} \leq \mathbf{0 . 0 5})$ & NS & NS & $\mathbf{N S}$ \\
\hline \multicolumn{4}{|l|}{ Nutrient Management Practices } \\
\hline Recommended Dose of Fertilizer (RDF) & 31.65 & 45.29 & 25.46 \\
\hline Site Specific Nutrient Management (SSNM) & 34.04 & 49.72 & 28.04 \\
\hline Farmers Practice (FP) & 29.67 & 41.44 & 24.83 \\
\hline S.E $(\mathbf{m}) \pm$ & 0.69 & 0.66 & 0.57 \\
\hline $\mathrm{CD}(\mathrm{P} \leq \mathbf{0 . 0 5})$ & 2.05 & 1.99 & 1.72 \\
\hline
\end{tabular}

Table.3 Effect of maize hybrids, plant geometry and nutrient management practices on Leaf Area Index (LAI) at different phenological stage

\begin{tabular}{|c|c|c|c|}
\hline Treatments & Knee high & Tasseling & Maturity \\
\hline \multicolumn{4}{|l|}{ Hybrid } \\
\hline Kanchan-101 & 2.52 & 5.69 & 3.83 \\
\hline Bio-605 & 2.60 & 5.93 & 4.30 \\
\hline S.E $(\mathbf{m}) \pm$ & 0.04 & 0.16 & 0.07 \\
\hline $\mathrm{CD}(\mathrm{P} \leq \mathbf{0 . 0 5})$ & NS & NS & NS \\
\hline \multicolumn{4}{|l|}{ Plant density } \\
\hline $60 \times 20 \mathrm{~cm}\left(83000\right.$ plants $\left.\mathrm{ha}^{-1}\right)$ & 2.52 & 4.90 & 3.13 \\
\hline $60 \times 15 \mathrm{~cm}(111111$ plants ha- 1$)$ & 2.56 & 5.81 & 4.07 \\
\hline S.E $(\mathrm{m}) \pm$ & 0.07 & 0.15 & 0.07 \\
\hline $\mathrm{CD}(\mathrm{P} \leq \mathbf{0 . 0 5})$ & NS & 0.58 & 0.27 \\
\hline \multicolumn{4}{|l|}{ Nutrient Management Practices } \\
\hline Recommended Dose of Fertilizer (RDF) & 2.63 & 5.84 & 3.24 \\
\hline Site Specific Nutrient Management (SSNM) & 2.69 & 6.59 & 5.38 \\
\hline Farmers Practice (FP) & 2.31 & 3.63 & 2.18 \\
\hline S.E $(\mathrm{m}) \pm$ & 0.08 & 0.20 & 0.10 \\
\hline $\mathrm{CD}(\mathrm{P} \leq \mathbf{0 . 0 5})$ & 0.25 & 0.59 & 0.30 \\
\hline
\end{tabular}


Table.4 Effect of maize hybrids, plant geometry and nutrient management practices on periodic plant height $(\mathrm{cm})$ at 30 days interval

\begin{tabular}{|c|c|c|c|c|}
\hline Treatments & 30 DAS & 60 DAS & 90 DAS & 120 DAS \\
\hline \multicolumn{5}{|l|}{ Hybrid } \\
\hline Kanchan-101 & 32.35 & 95.56 & 196.46 & 197.71 \\
\hline Bio-605 & 33.69 & 99.20 & 209.24 & 209.41 \\
\hline S.E $(\mathrm{m}) \pm$ & 0.56 & 1.03 & 3.48 & 4.35 \\
\hline $\mathrm{CD}(\mathrm{P} \leq \mathbf{0 . 0 5})$ & NS & NS & NS & NS \\
\hline \multicolumn{5}{|l|}{ Plant density } \\
\hline $60 \times 20 \mathrm{~cm}\left(83000\right.$ plants ha $\left.^{-1}\right)$ & 31.74 & 93.49 & 194.96 & 195.46 \\
\hline $60 \times 15 \mathrm{~cm}\left(111111\right.$ plants $\left.\mathrm{ha}^{-1}\right)$ & 34.30 & 101.27 & 210.74 & 211.66 \\
\hline S.E $(\mathbf{m}) \pm$ & 0.39 & 1.77 & 2.29 & 3.06 \\
\hline $\mathrm{CD}(\mathrm{P} \leq \mathbf{0 . 0 5})$ & 1.53 & 6.95 & 8.97 & 12.01 \\
\hline \multicolumn{5}{|l|}{ Nutrient Management Practices } \\
\hline Recommended Dose of Fertilizer (RDF) & 33.52 & 100.62 & 212.23 & 212.36 \\
\hline $\begin{array}{l}\text { Site Specific Nutrient Management } \\
\text { (SSNM) }\end{array}$ & 38.34 & 108.17 & 224.75 & 226.13 \\
\hline Farmers Practice (FP) & 27.20 & 83.35 & 171.57 & 172.19 \\
\hline S.E $(\mathrm{m}) \pm$ & 0.70 & 1.26 & 5.35 & 3.33 \\
\hline $\mathrm{CD}(\mathrm{P} \leq \mathbf{0 . 0 5})$ & 2.09 & 3.76 & 16.03 & 9.99 \\
\hline
\end{tabular}

The overall improvement in crop growth under the influence of optimum nutrition involving nutrient management practices could be ascribed to their potential role in modifying soil and plant environment conducive for better development of both morphological and biochemical components of the plant growth that increase efficiency of physiological processes of plant system. Amongst nutrients, nitrogen is considered to be a vitally important plant nutrient. $\mathrm{N}$ is the integral part of the chlorophyll molecule, which is the primary absorber of light energy needed for photosynthesis. Deficiency of $\mathrm{N}$ and chlorophyll means that crops will not efficiently utilize sunlight as an energy source to carry out essential functions such as nutrient uptake. It is a component of vitamins and energy systems in plants. Nitrogen is an essential component of amino acids, which form plant proteins. Besides these, it is also a constituent of certain organic compounds of physiological importance (Havlin et al., 2005 and Brady and Weil 2002). Phosphorous improves various metabolic and physiological processes and is also known as "energy currency" in plant which is subsequently used for vegetative and reproductive growth through phosphorylation. In addition to this vital metabolic role, $\mathrm{P}$ is a structural component of nucleic acid, phytin, phospholipids and enzymes. An adequate supply of phosphorous to plant is important in laying down the primordial for its reproductive part. It also increases the initiation of both first and second rootlets and their development. The extensive root system helps in extracting the maximum nutrients and water from the soil (Tondon, 1987).

The data on chlorophyll content of maize plant as influenced by maize hybrids, planting densities and nutrient management practices were recorded at 30 day interval and 
statistically analyzed data observed during the course of investigation have been presented in Table 1. Plant population did not significantly influence chlorophyll content. However, application of SSNM recorded significantly higher chlorophyll content (34.04, 49.72 and 28.04) over RDF and FP at knee high tasseling as well as maturity respectively.

On the basis of the results emanated from present investigation conducted during kharif 2017, it can be concluded that among different nutrient management practices Site Specific Nutrient Management (SSNM) realized significantly better growth of maize. All growth parameters were positively influences by SSNM. Under the $60 \times 20 \mathrm{~cm}$ spacing $\left(83000\right.$ plants $\left.\mathrm{ha}^{-1}\right)$ number of functional leaves per plant showed significant effect. However plant height and leaf area index were higher under $60 \times 15 \mathrm{~cm}$ spacing (111111 plants ha ${ }^{-1}$ ). Thus from present study it can be concluded that maize hybrid under $60 \times 20 \mathrm{~cm}$ spacing $\left(83,000\right.$ plants ha $\left.^{-1}\right)$ with Site Specific Nutrient Management (SSNM) found better suited for temperate conditions of Kashmir.

\section{References}

Abuzar, M. R., Sadozai, G. U., Baloch, M. S., Baloch, A. A., Shah, I. H., Javaid, T. and Hussain, N. 2011. Effect of Plant Population Densities on Yield of Maize. The Journal of Animal and Plant Science 21: 692-695.

Anonymous. 2015. Digest of Statistics. Directorate of Economics and Statistics, Planning and Development Department, Govt. of Jammu and Kashmir, India pp. 81-129.

Aravinth, V., Kuppuswamy, G. and Ganapathy, M. 2011. Growth and yield of baby corn (Zea mays) as influenced by intercropping, planting geometry and nutrient management. Indian Journal of
Agricultural Sciences 81(9): 875-877.

Azam, S., Ali, M., Amin, M., Bibi, S. and Arif, M. 2007. Effect of plant population on maize hybrids. Journal of Agricultural and Biological Science 2(1): 104-111.

Bhatt, P. S. 2012. Response of sweet corn hybrid to varying plant densities and nitrogen levels. African Journal of Agricultural Research 7: 6158-6166.

Brady, N. and Weil R. 2002. The Nature and properties of soils, 13th Edition. Prentice Hall. Upper Saddle River, New Jersey pp. 960.

Bruns, H. A. and Abbas, H. C. 2005. Ultra high plant population and nitrogen fertility effects on corn in the Mississippi valley. Agronomy Journal 97: 1136.

Cochran, W. G. and Cox, G. M. 1963. Wiley International (eds.): experimental Designs, $2^{\text {nd }}$ Edn. New York pp. 293299.

Economic Survey, 2018. Mofapp. nic. in. 8080/economic survey.

Havlin, J. L., Beaton, J. D., Tisdale, S. L. and Nelson, W. L. 2005. Soil fertility and fertilizers. An introduction to nutrient management. Prentice hall, New Jersy.

Mandić, V. 2011. Fenotipski Odgovor stay green hibrida kukuruza napovećanugustinuuseva. Doktorska Disertacija, Poljoprivrednifakultet Univerziteta u Beogradu, Republika Srbija pp. 1-162.

Monnveux, P., Zaidi, P. H. and Sanchezc, C. 2005. Population density and low nitrogen effects on yield and associated trates in Tropical maize. Crop Science 45: 103-106.

Peykarestan, B. and Seify, M. 2012. Impact of sowing date on growth yield attributes of popcorn growth under different density. International Research Journal of Applied and Basic Sciences 3: 85-91. 
Sangoi, L., Gracietti, M. A., Rampzzo, C. and Bianchetti, P. 2002. Response of Brazilian maize hybrids from different eras to changes in plant density. Field Crops Research 79: 39-51.

Satyanarayana, T., Majumdar, K., Pampolino, M., Johnston, A. M., Jat, M. L., Kuchanur, P., Sreelatha, D., Shekhar, J. C., Kumar, Y., Maheswaran, R., Karthikeyan, R., Velayutham, A., Dheebakaram, G., Sakthivel, N., Vallalkannan, N., Bharathi, C., Sherene, T., Suganaya, S., Janaki, P., Baskar, R., Ranjith, T. H., Shivamurthy, D., Aladakatti, Y. R., Chiplomkar, D., Gupta, R., Biradar, D. P., Jayaraman, S. and Patil, S. G. 2013. Nutrient Expert TM: A tool to optimize nutrient use and improve productivity of maize. Better Crops-South Asia 97(1): 21-24.

Singh, M. K., Singh, R. N. and Singh, V. K. 2011. Effect of organic and inorganic sources of nutrient on growth, yield, quality and nutrient uptake by Baby corn (Zea mays). Annuals of Agriculture Research 32: 93-99.
Singh, Y. V., Sharma, P. K. and Meena, R. 2014. Effect of soil test crop response technology on productivity and economics of rice crop of Varanasi district of Uttar Pradesh. The Journal of Rural and Agricultural Research 14: 77-80.

Special Maize Report, 2016, www.geofin.co.in

Thakur, A. K., DushyanT, S. T., Patel, R. K., Pradhan, A. and Prafull, K. 2015. Effect of different plant geometry and nitrogen levels, in relation to growth characters, yield and economics on sweet corn (Zea mays Sachharatal.) At bastar plateau zone. The Bioscan 10: 1223-1226.

Tondon, H. L. S. 1987. Phosphorus research and agriculture production in India. Fertilizer Development and Constation Organization, New Delhi.

Uhart, S. A. and Andrade, F. H. 1995. Nitrogen deficiency in maize: I Effect on the crop growth development, dry matter partitioning and kernel set. Crop Science 35: 1375-1383.

\section{How to cite this article:}

Ayman, B.A. Alie, Shayan, Saima and Jahangeer A. Baba. 2019. Effect of Planting Density and Nutrient Management Practices on the Growth Parameters of Maize Hybrids under Temperate Conditions of Kashmir. Int.J.Curr.Microbiol.App.Sci. 8(01): 2317-2325. doi: https://doi.org/10.20546/ijcmas.2019.801.243 